ISSN : 2356-4164

\title{
LEMBAGA NEGARA PEMBENTUK UNDANG-UNDANG
}

\author{
Ni Putu Niti Suari Giri
}

Fakultas Hukum Universitas Udayana Denpasar Bali

\begin{abstract}
ABSTRAK
Penelitian ini dilakukan dengan tujuan untuk mengetahui mengenai lembaga negara pembentuk undang-undang. Penelitian ini mengkaji Undang-Undang Dasar 1945 sebelum amandemen dan sesudah amandemen, juga mengkaji dengan UndangUndang Nomor 12 Tahun 2011 Tentang Pembentukan Peraturan PerundangUndangan.

Metode yang digunakan dalam penelitian ini, yaitu menggunakan metode penelitian yuridis normatif. Bahan atau data yang digunakan untuk menjawab permasalahan yang dibahas dalam penelitian ini, dengan mencari dan mengumpulkan bahan yang berasal dari data kepustakaan.

Hasil dari penelitian ini menunjukkan bahwa lembaga negara pembentuk undang-undang adalah lembaga negara yang ikut dalam proses pembentukan undangundang, yaitu terdiri dari DPR, Presiden dan DPD. Hanya saja kekuasaan untuk membentuk undang-undang,berada ditangan DPR.
\end{abstract}

Kata Kunci :Lembaga Negara, Undang-Undang, Kekuasaan, DPR, Presiden, DPD

\section{ABSTRACT}

This study was conducted to find out about the institutions state legislature. This study examine the association the Constitution 1945 before the amandement and after amandement, also review by Act No. 12 of 2011 Concerning the Establishment of Regulatory Legislation.

The method used in this study, using normative juridical research method. Materials or data that is used to address the issue discussed in this study, to find and collect ingredients derived from literature data.

The result of this study indicate that the state legislature is the state institution that participates in the formation of la, which is composed of DPR, President and DPD. The power to legislate, belongs to DPR.

Keywords : State institution, The Law, power, DPR, President, DPD

\begin{abstract}
Pendahuluan
Awal mula mengenai kelembagaan negara adalah teori kekuasaan dalam negara. Terdapat tiga kekuasaan utama yang ada dalam suatu negara agar pemerintahan dapat berjalan dengan baik. Teori mengenai tiga kekuasaan negara ini, diawali Jurnal Komunikasi Hukum
\end{abstract}

dengan adanya pendapat dari John Locke yang memisahkan tiga kekuasaan negara menjadi Kekuasaan Legislatif (merupakan kekuasaan yang untuk membentuk atau membuat aturan), Kekuasaan Eksekutif (yaitu kekuasaan untuk menjalankan aturan) dan Kekuasaan Federatif (kekuasaan Universitas Pendidikan Ganesha | 84 
yang berkaitan dengan pelaksanaan hubungan luar negeri atau kerja sama dengan negara lain). Kemudian Montesqueue mengemukakan pendapatnya mengenai Trias Politica yang membagi tiga kekuasaan negara menjadi Kekuasaan Legislatif (kekuasaan untuk membentuk aturan), Kekuasaan Eksekutif (kekuasaan untuk menjalankan atau melaksanakan aturan yang telah dibuat) dan terakhir adalah Kekuasaan Yudisial (yaitu kekuasaan untuk mengawasi dan mengadili apabila terjadi penyimpangan dari pelaksanaaan aturan tersebut).

Dalam Bahasa Belanda, lembaga negara disebut dengan staatorgaan yang dalam Kamus Hukum BelandaIndonesia, staatorgaan diterjemahkan sebagai alat kelengkapan negara. Hans Kelsen mengemukakan mengenai konsep organ negara dalam arti yang luas yaitu barang siapa yang menjalankan suatu fungsi yang ditetapkan oleh tata hukum adalah suatu organ. Fungsi yang dimaksud, baik berupa fungsi pembuatan norma atau fungsi dari penerapan norma, yang pada akhirnya ditujukan kepada pelaksanaan sanksi hukum. Jadi berdasarkan pengertian tersebut, organ adalah individu yang menjalankan suatu fungsi tertentu yang mana kualitas seseorang dibentuk oleh fungsinya. Seperti lembaga legislatif, sebagai lembaga yang menetapkan aturan (fungsi legislasi), yang mana lembaga ini dipilih oleh rakyat, presiden yang menjalankan fungsi pemerintahan atau hakim yang menghukum pelaku kejahatan (fungsi yudisial). Kemudian Hans Kelsen juga mengemukakan mengenai konsep Jurnal Komunikasi Hukum organ yang lebih sempit (secara material) yang lebih menekankan pada pegawai negeri yang menempati kedudukan tertentu dan menjalankan fungsi organ negara. Hakim merupakan kategori organ negara dalam pengertian material ini, karena hakim diangkat merupakan pegawai negeri yang menjalankan fungsi yudisial sedangkan untuk presiden dan lembaga legislatif bukan pegawai negeri (Hans Kelsen, 2007).

Dilihat dari segi konsep, tujuan dibentuknya lembaga negara adalah untuk menjalankan fungsi pemerintahan atau menyelenggaraan fungsi negara. Lembaga-lembaga negara tersebut harus bekerja sama sehingga membentuk suatu kesatuan untuk merealisasikan secara praktis fungsi negara dan secara ideologis mewujudkan tujuan negara jangka panjang yang oleh Prof. Sri Soemantri diistilahkan dengan actual governmental process (Firmansyah Arifin et. Al, 2005).

Perkembangan lembaga negara di Indonesia, terdapat perubahan yang sangat signifikan antara masa sebelum amandamen dengan setelah diamandemennya Undang-Undang Dasar 1945. Sebelum diamandemen, tidak ada ketentuan mengenai istilah lembaga negara sehingga menyulitkan dalam mengidentifikasi dan memaknai lembaga penyelenggara negara. Konstitusi RIS 1949 menggunakan istilah alat-alat kelengkapan federal. Istilah badan secara konsisten dipergunakan dalam batang tubuh dan penjelasan Undang-Undang Dasar 1945. Peristilahan lembaga negara banyak muncul dalam ketetapanketetapan MPR, sehingga mulai Universitas Pendidikan Ganesha | 85 
ditemukannya konsep lembaga negara di Indonesia yang membagi kedudukan lembaga negara ke dalam dua kategori yaitu lembaga tertinggi negara (MPR) dan lembaga tinggi negara (Presiden, DPA, DPR, BPK dan MA) (Firmansyah Arifin et. Al, 2005).

Setelah amandemen UndangUndnag dasar 1945, penataan sistem kelembagaan negara pun dilakukan. Penataan tersebut dilakukan melalui perubahan fungsi dan wewenang beberapa lembaga negara ataupun dengan pembentukan lembaga negara baru, yang mengakibatkan biasnya konsep lembaga negara yang menimbulkan berbagai macam penafsiran. Salah satu penafsiran tersebut, membagi lembaga negara ke dalam dua kategori. Pertama, kategori lembaga negara utama (main state's organ) yaitu MPR, DPR, DPD, Presiden. MA dan MK. Kedua, kategori lembaga negara bantu (auxiliary state's organ) yaitu lembaga-lembaga negara di luar ke enam lembaga negara utama (Firmansyah Arifin et. Al, 2005).

Undang-Undang Dasar 1945 yang telah mengalami amandemen sebanyak empat kali, yang sekarang disebut dengan Undang-Undang Dasar Negara Republik Indonesia Tahun 1945, menganut Teori Pembagian Kekuasaan. Hal ini dapat dilihat dari adanya beberapa lembaga negara yang disebutkan dalam Undang-Undang Dasar Negara Republik Indonesia Tahun 1945 yang memiliki kekuasaan seperti yang dinyatakan dalam Teori Pembagian Kekuasaan. Lembagalembaga negara tersebut adalah DPR sebagai lembaga negara yang menjalankan fungsi kekuasaan legislatif, Presiden sebagai lembaga Jurnal Komunikasi Hukum negara yang menjalankan fungsi kekuasaan eksekutif, kemudian MA dan MK sebagai lembaga negara yang menjalankan fungsi kekuasaan yudisial. Ketiga lembaga tersebut memiliki wewenang, tugas dan fungsinya masing-masing di dalam pemerintahan yang telah diatur di dalam pasal-pasal Undang-Undang Dasar Negara Republik Indonesia Tahun 1945. Jadi dengan adanya lembaga-lembaga negara tersebut diharapkan pemerintahan Indonesia dapat berjalan dengan baik, karena telah ada lembagalembaga negara yang membuat aturan, melaksanakan aturan dan mengawasi jalannya pelaksanaan aturan itu.

Pada Undang-Undang Dasar Negara Republik Indonesia Tahun 1945 kekuasaan yang dimiliki oleh Presiden diatur di dalam Bab III (Kekuasaan Pemerintahan Negara). Mengenai kekuasaan yang dimiliki oleh DPR diatur dalam Bab VII (Dewan Perwakilan Rakyat). Mengenai kekuasaan yang dimiliki oleh MA diatur dalam Bab IX (Kekuasaan Kehakiman).

Pada Pasal 20 ayat (1) UndangUndang Dasar Negara Republik Indonesia Tahun 1945 yang mengatur: "Dewan Perwakilan Rakyat memegang kekuasaan membentuk undangundang." Dikaitkan dengan Teori Pembagian Kekuasaan tersebut, maka DPR merupakan lembaga legislatif yang memiliki kekuasaan untuk membentuk undang-undang, sedangkan Presiden sebagai lembaga eksekutif, dalam teori pembagian kekuasaan memiliki kekuasaan eksekutif yaitu kekuasaan untuk melaksanakan undang-undang. Kemudian pada Pasal 20 ayat (2) dan ayat (4), mengenai keterlibatan Universitas Pendidikan Ganesha | 86 
Presiden di dalam pembentukan undang-undang, yaitu pada Pasal 20 ayat (2) mengatur bahwa rancangan undang-undang dibahas oleh DPR dan Presiden untuk mendapatkan persetujuan bersama. Selanjutnya Pasal 20 ayat (4) mengatur bahwa rancangan undang-undang yang telah disetujui bersama oleh DPR dan Presiden disahkan oleh Presiden, Juga Pasal 5 ayat (1) mengatur bahwa Presiden berhak mengajukan rancangan undang-undang kepada Dewan Perwakilan Rakyat. Jadi di sini terlihat, Presiden mempunyai peranan yang sangat penting dalam pembentukan suatu undang-undang. Bila ditinjau dari sudut formulasi norma Pasal 20 ayat (1) , secara jelas mengatur Dewan Perwakilan Rakyat memegang kekuasaan membentuk undang-undang dan sama sekali tidak ada kaitannya dengan Presiden. Namun pada Pasal 20 ayat (2) dan ayat (4) muncul kata Presiden. Jadi antara Pasal 20 ayat (1) dengan Pasal 20 ayat (2) dan ayat (4), terjadi kekaburan dan ketidaksinkronnan norma mengenai kekuasaan dari lembaga legislatif dengan kewenangan yang dimiliki oleh Presiden dalam ikut membentuk undang-undang sehinnga Presiden juga seolah-olah memiliki kekuasaan untuk membentuk undang-undang.

Berdasarkan uraian dari latar belakang tersebut, maka penulis tertarik untuk melakukan penelitian hukumdalam lingkup hukum kelembagaan negara Indonesia untuk berusaha menemukan apakahyang dimaksud dengan "Lembaga Negara Pembentuk Undang-Undang”.

\section{Pembahasan}

Sebelum membahas lebih jauh mengenai apa yang dimaksud dengan lembaga pembentuk undang-undang, perlu dipahami terlebih dahulu mengenai konsep dari pembentukan undang-undang itu sendiri. Hal ini dapat dilihat dari pengaturan Pasal 1 angka 1 Undang-Undang Nomor 12 Tahun 2011 tentang Pembentukan Peraturan Perundang-Undangan. Pasal 1 angka 1 ini mengatur bahwa yang dimaksud dengan pembentukan peraturan perundang-undangan adalah pembuatan peraturan perundangundangan yang mencakup tahapan perencanaan, penyusunan, pembahasan, pengesahan atau penetapan dan pengundangan.

Apabila dikaitkan dengan pembentukan sebuah aturan yang baik, proses pembentukan peraturan perundang-undangan tersebut sudah mencakup ketujuh kriteria atau kategori yang dikemukakan oleh Ann Seidmann, Robert R. Seidmann dan Nalin Abeyserkere dalam teorinya yang disebut dengan Teori ROCCIPI. Teori ini merupakan identifikasi tujuh faktor yang seringkali menimbulkan masalah yang berkaitan dengan berlakunya suatu peraturan perundang-undangan. Ketujuh kategori ini dapat digunakan untuk mendapatkan masukan tentang proposisi penjelasan yang dapat diuji dan saling berkaitan, yang terdiri dari Rule (Peraturan), Opportunity (Kesempatan), Capacity (Kemampuan), Communication (Komunikasi), Interest (Kepentingan), Process (Proses),dan Ideology (Ideologi) (Ann Seidman, Robert B. Seidmann dan Nalin Abeyserkere, 2002). 
Kategori-kategori ROCCIPI ini dibagi kembali menjadi dua kelompok faktor penyebab, yaitu Faktor Subjektif dan Faktor Objektif. Faktor subjektif berkaitan dengan factor apa yang ada dalam benak para pelaku peran, yaitu berupa kepentingan-kepentingan mereka (Interest) dan ideologi-ideologi yang terdiri dari nilai-nilai dan sikap mereka (Ideology). Hal-hal ini merupakan apa yang awalnya diidentifikasikan kebanyakan orang berdasarkan naluri sebagai alasan dari perilaku masyarakat. Kemudiann untuk kategori faktor objektif terdiri dari Rule, Opportunity, Capacity, Communication dan Process. Faktor objektif ini lebih memusatkan perhatian pada factor penyebab perilaku kelembagaan yang menghambat pemerintahan yang bersih.

Berdasarkan pengaturan Pasal 1 Angka 1 tersebut, terdapat lima tahapan di dalam pembentukan peraturan perundang-undangan, yaitu :

1. Tahapan Perencanaan

Laporan hasil penelitian dari pembuat undang-undang harus dimulai dengan memberikan fakta-fakta untuk membuktikan hipotesa deskriptif tentang gambaran manifestasi dari kesulitan tersebut dengan maksud membuat RUU yang efektif. Laporan juga harus menyebutkan perilaku siapa dan yang bagaimana yang menggambarkan kesulitan tersebut.

Tahapan perencanaan ini, merupakan tahapan yang dilakukan oleh lembaga pembentuk undangundang untuk menentukan rancangan undang-undang apa saja yang akan diprioritaskan akan dibentuk. Rancangan undang-undang yang akan Jurnal Komunikasi Hukum diprioritaskan tersebut dituangkan ke dalam Prolegnas untuk setahun ke depan. Pasal 16 Undang-Undang Nomor 12 Tahun 2011, mengatur bahwa perencanaan penyusunan undang-undang dilakukan dalam Prolegnas. Prolegnas ini disusun oleh DPR dan Pemerintah. Hasil dari penyusunan Prolegnas di lingkungan DPR dan Pemerintah dibahas bersama yang kemudian pelaksanaannya dikoordinasikan oleh DPR melalui Badan Legislasi. Pasal 19 nya mengatur pada ayat (1) Prolegnas sebagaimana dimaksud pada Pasal 16 memuat program pembentukan UndangUndang dengan judul Rancangan Undang-Undang, materi yang diatur, dan keterkaitannya dengan Peraturan Perundang-Undangan lainnya dan ayat (2) nya mengatur mengenai materi yang diatur dan keterkaitannya dengan Peraturan Perundang-Undangan merupakan keterangan mengenai konsepsi Rancangan Undang-Undang yang meliputi latar belakang dan tujuan penyusunan; sasaran yang ingin diwujudkan; dan jangkauan dan arah pengaturan.

Pada tahapan ini juga merupakan tahapan penyiapan dari naskah akademik, karena berdasarkan pengaturanPasal 19 ayat (3) yaitu materi yang diatur mengenai konsepsi Rancangan Undang-Undang yang meliputi latar belakang dan tujuan penyusunan; sasaran yang ingin diwujudkan; dan jangkauan dan arah pengaturan.yang telah melalui pengkajian dan penyelerasan dituangkan ke dalam Naskah Akademik. Juga Pasal 43 ayat (3) mengatur Rancangan Undang-Undang Universitas Pendidikan Ganesha | 88 
yang berasal dari DPR, Presiden, atau DPD harus disertai Naskah Akademik.

\section{Tahapan Penyusunan}

Tahapan ini merupakan tahapan penyusunan dari hasil penelitian dan pengkajian yang telah dilakukan terhadap rancangan undnag-undnag yang akan diajukan. Penyusunan terhadadap perumusan norma dalam pasal rancangan undang-undang berdasarkan hasil pengkajian dalam naskah akademik. Untuk mentransformasikan naskah akademik ke dalam bentuk pasal-pasal, perumusan suatu pasal dalam RUU menurut Made Subawa perumusan satu pasal dalam suatu aturan haruslah mengandung satu norma, berdasarkan pendapat dari Philipus M. Hadjon yang dikutip dari acara dengar pendapat dengan para pakar pada tanggal 6 Desember 1999 dengan panitian Ad Hoc I Badan Pekerja MPR di Jakarta, yaitu (Made Subawa, 2003) :

“.... salah satu prinsip dasar di dalam perumusan satu pasal bahwa rumusan itu harus ada kepastian, dapat diterapkan ....."

"Patokannya dalam merumuskan Pasal itu, jangan lupa satu Pasal itu satu norma, sehingga pembagian harus tahu apa dibagi dalam ayat, dalam huruf atau kedalam angka itu hal-hal teknis perlu diperhatikan."

Sehingga untuk merumuskan pasal-pasal dalam rancangan undangundang yang berasal dari isi naskah akademik haru benar-benar memperhatikan perumusan satu pasal satu norma ini. Agar nantinya setelah menjadi undang-undang, tidak menghasilkan pasal-pasal yang pengaturannya menafsirkan hal yang ganda atau bertentangan.

Jurnal Komunikasi Hukum
3. Tahapan Pembahasan

Laporan hasil penelitian pembuat rancangan harus secara sistematis mengusulkan menguji pilihan-pilihan hipotesa penjelasan tentang sebabsebab perilaku bermasalah dari pelaku peran. Juga untuk membenarkan hipotesis tersebut, laporan harus mengatur bukti-bukti untuk menunjukkan faktor-faktor khusus yang menyebabkan perilaku tersebut (Ann Seidman, Robert B. Seidmann dan Nalin Abeyserkere; 112).

Pada tahap pembahasan ini, berdasarkan pengaturan Pasal 20 ayat (2) Undang-Undang Dasar Negara Republik Indonesia tahun 1945 setiap RUU dibahas oleh DPR dan Presiden untuk mendapatkan persetujuan bersama. DPD juga dapat ikut membahas RUU, hanya yang berkaitan dengan otonomi daerah; hubungan pusat dan daerah; pembentukan, pemekaran dan penggabungan daerah; pengelolaan sumber daya alam dan sumber daya ekonomi lainnya; serta memberikan pertimbangan kepada DPR atas RUU APBN dan RUU yang berkaitan dengan pajak, pendidikan dan agama (Pasal 22D ayat (2)).

4. Tahapan Pengesahan atau Penetapan

Setelah sebuah RUU mendapatkan persetujuan bersama antara DPR dan Presiden, tahap selanjutnya adalah pengesahan. Presiden mengesahkan RUU tersebut menjadi undang-undang dengan membubukan tanda tangan.

5. Tahapan Pengundangan

Tahapan terakhir yaitu pengundangan. Undang-undang yang telah disahkan diundangkan dengan menempatkannya ke dalam Lembaran

Universitas Pendidikan Ganesha | 89 
Negara Republik Indonesia. Setelah diundangkan dan dilaksanakannya suatu undang-undang, maka para pembuat undang-undang memerlukan masukan untuk menentukan apakah pelaku sosial (termasuk lembaga pelaksana yang ditunjuk) berperilaku sebagaimana ditentukan dan akan menghasilkan akibat yang diharapkan (Ann Seidman, Robert B. Seidmann dan Nalin Abeyserkere; 113).

Berpijak dari Pasal 20 ayat (1) yang menyatakan bahwa Dewan Perwakilan Rakyat yang memegang kekuasaan membentuk undangundang, jadi terlihat jelas bahwa DPR merupakan lembaga negara yang memiliki kekuasaan untuk membentuk undang-undang. Akan tetapi, apabila dilihat dari pengajuan rancangan undang-undang dan keikutsertaan, sesuai dengan Pasal 5 ayat (1) dan Pasal 22D ayat (1), Presiden dan DPD dapat dikatakan sebagai lembaga pembentuk undang-undang. Hal ini dapat dilihat dari keterlibatan ketiga lembaga tersebut di dalam proses pembentukan undang-undang.

1. Dewan Perwakilan Rakyat (DPR)

Sebelum adanya amandemen terhadap Undang-Undang Dasar,1945 kekuasaan untuk membentuk UndangUndang berada di tangan Presiden. Hal ini sesuai dengan ketentuan Pasal 5 ayat (1) Undang-Undang Dasar sebelum amandemen yang berbunyi "Presiden memegang kekuasaan membentuk undang-undang dengan persetujuan Dewan Perwakilan Rakyat" dan pada Pasal 20 ayat (1) berbunyi "Tiap-tiap undang-undang menghendaki persetujuan Dewan Perwakilan Rakyat". Jadi dapat dikatakan berdasarkan bunyi pasal Jurnal Komunikasi Hukum tersebut, Presidenlah yang sebagai lembaga legislatif dan DPR hanya memiliki kekuasaan untuk memberikan persetujuan semata di dalam pembentukan undang-undang.

Kemudian pada Pasal 20 ayat (1) Undang-Undang Dasar Negara 1945 setelah amandemen berbunyi "Dewan Perwakilan Rakyat memegang kekuasaan untuk membentuk Undangundang". Lalu pada Pasal 20 ayat (2) berbunyi "Setiap Rancangan UndangUndang dibahas oleh Dewan Perwakilan Rakyat dan Presiden untuk mendapatkan persetujuan bersama".

Pengalihan kekusaan membentuk undang-undang dari tangan Presiden ke tangan DPR dalam Undang-Undang Dasar 1945 ke Undang-Undang Dasar Negara Republik Indonesia Tahun 1945, menegaskan bahwa Indonesia menganut sistem pembagian kekuasaan. Terlihat dengan adanya pembagian kekuasaan yang jelas terhadap lembaga legislatif yang berada di tangan DPR dan lembaga eksekutif yang dipegang oleh Presiden. Dalam Undang-Undang Dasar sebelum amandemen, dinyatakan DPR hanya memiliki tugas untuk menyetujui undang-undang saja dan kekuasaan membentuk undang-undang ada di tangan Presiden sedangkan setelah amandemen, kekuasaan membentuk undang-undang telah dialihkan dari tangan Presiden kepada DPR.

2. Presiden

Pasal 4 ayat (1) Undang-Undang Dasar Negara Republik Indonesia Tahun 1945 berbunyi "Presiden Republik Indonesia memegang kekuasaan pemerintahan menurut Undang-Undang Dasar". Dalam pasal tersebut, yang dimaksudkan dengan Universitas Pendidikan Ganesha | 90 
Presiden memegang kekuasaan pemerintahan, yaitu menunjuk kepada pengertian Presiden menurut sistem pemerintahan presidensiil. Pada pemerintahan presidensiil, tidak terdapat perbedaan antara Presiden yang berkedudukan sebagai kepala negara dan Presiden berkedudukan sebagai kepala pemerintahan. Presiden adalah Presiden, yaitu merupakan jabatan yang memegang kekuasaan pemerintahan negara menurut undangundang dasar. Akibat adanya pengakuan atas kedua kedudukan Presiden yaitu baik sebagai kepala negara sekaligus sebagai kepala pemerintahan, menyebabkan timbulnya kebutuhan yuridis untuk membedakan keduanya dalam pengaturan terhadap hal-hal yang lebih teknis dan operasional. Kapasitas Presiden sebagai kepala negara dan kepala pemerintahan tidak dapat dipisahkan (Jimly Asshiiddiqie, 2006).

Pasal 20 ayat (2) Undang-Undang Dasar 1945 yang telah diamandemen mengatur RUU dibahas oleh DPR dan Presiden untuk mendapatkan persetujuan bersama. Makna dari kata mendapat persetujuan bersama ini, dapat dikatakan mirip dengan pola yang dianut oleh Belanda, karena istilah bersama-sama ini di Belanda terdapat dalam art. 81 Grondwet yang disebut dengan cowetgeving atau medewetgeving, sehingga UndangUndang Dasar Negara Republik Indonesia Tahun 1945 menganut sistem pembentukan undang-undang secara medewetgeving (Philipus $\mathrm{M}$. hadjon, 1999).

Presiden hanya memiliki keuasaan untuk menjalankan pemerintahan sebagai lembaga Jurnal Komunikasi Hukum eksekutif. DPR lah yang merupakan lembaga yang memiliki kekuasaan legislatif. Kekuasaan yang dimiliki oleh Presiden di dalam proses pembentukan undang-undang hanya berupa; dapat menyampaikan rancangan undangundang, membahas rancangan undangundang bersama DPR untuk mendapatkan persetujuan bersama dan mengesahkan rancangan undangundang yang telah disetujui menjadi undang-undang, yang memang itu merupakan bagian dari kekuasaan yang dimiliki oleh Presiden sebagai lembaga yang memegang kekuasaan menjalankan pemerintahan.

3. Dewan Perwakilan Daerah (DPD)

DPD awalnya dibentuk dalam rangka mereformasi struktur parlemen Indonesia menjadi sistem dua kamar atau bicameral yang terdiri atas DPR dan DPD. Dengan adanya DPD diharapkan proses legislasi dapat diselenggarakan berdasarkan sistem double check yang memungkinkan representasi kepentingan seluruh rakyat secara relatif dapat disalurkan dengan basis sosial yang lebih luas. DPR adalah cerminan representasi politik, sedangkan DPD cerminan prinsip representasi teritorial atau regional (Jimly Asshiiddiqie, 141).

Kedudukan DPD sama dengan DPR sebagai lembaga perwakilan rakyat. Perbedaannya, hanya terletak pada penekanan posisi anggota DPD sebagai wakil dan representatif dari daerah. Pembentukan DPD sendiri bertujuan untuk memberikan kesempatan kepada orang-orang daerah untuk ikut serta dalam pengambilan kebijakan di tingkat nasional, khususnya yang terkait dengan kepentingan daerah. Meskipun

Universitas Pendidikan Ganesha | 91 
dalam struktur kenegaraan kedudukan DPD sejajar dengan DPR, tapi kewenangan yang dimiliki oleh DPD sangat terbatas (Firmansyah Arifin; 75).

Mengenai kekuasaan yang dimiliki oleh DPD disebutkan dalam Pasal 22D Undang-Undang Dasar Negara Republik Indonesia Tahun 1945. Pada ayat (1) dinyatakan DPD dapat mengajukan rancangan undangundang kepada DPR yang berkaitan dengan otonomi daerah, hubungan pusat dan derah, pembentukan dan pemekaran serta penggabungan daerah, pengelolaan sumber daya alam dan sumber daya ekonomi lainnya serta berkaitan dengan perimbangan keuangan pusat dan daerah. Jadi DPD hanya dapat mengajukan rancangan undang-undang yang berkaitan dengan daerah saja.

Kemudian pada Pasal 22D ayat (2) disebutkan bahwa DPD ikut membahas rancangan undang-undang yang berkaitan dengan otonomi daerah, hubungan pusat dan derah, pembentukan dan pemekaran serta penggabungan daerah, pengelolaan sumber daya alam dan sumber daya ekonomi lainnya serta berkaitan dengan perimbangan keuangan pusat dan daerah, serta memberikan pertimbangan kepada DPR atas rancangan undang-undang anggaran pendapatan dan belanja negara dan rancangan undang-undang yang berkaitan dengan pajak, pendidikan dan agama. Sehingga dapat dilihat kekuasaan yang dimiliki oleh DPD hanya sebatas membahas rancangan undang-undang yang berkaitan dengan hal-hal yang berkaitan dengan daerah saja.

Jurnal Komunikasi Hukum

\section{Penutup}

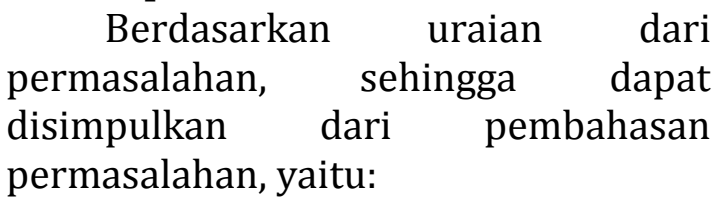

Bahwa berdasarkan ketentuan Pasal 20 ayat (1) Undang-Undang Dasar Negara Republik Indonesia Tahun 1945, DPR adalah lembaga negara yang memiliki kekuasaan membentuk undang-undang. Akan tetapi jika dilihat dari proses atau mekanisme pembentukan undangundang itu sendiri dapat dilihat ada beberapa lembaga negara yang terlibat selain DPR, yaitu Presiden dan DPD. Presiden dan DPD di sini perannya sebagai lembaga negara pembentuk undang-undang yang membantu tugas dari DPR di dalam proses pembentukan undangundang.Kekuasaan untuk membentuk undang-undang, tetap berada ditangan DPR.

\section{Saran}

Saran yang dapat diberikan berdasarkan uraian dari kesimpulan tersebut di atas, yaitu :

$\begin{array}{llr}\text { Sebaiknya dalam } & \text { perumusan } \\ \text { suatu pasal sebuah } & \text { peraturan } \\ \text { perundang-undangan } & \text { hendaknya }\end{array}$
dibuat satu pasal itu menganut satu norma. Jangan sampai dalm satu pasal terdapat pemuatan lebih dari satu norma yang akhirnya dapat menyebabkan salah tafsir akibat dari ketidakjelasan pengaturannya.

\section{Daftar Pustaka Buku- Buku}

Anwar, Chairul, 1999, Konstitusi Dan Kelembagaan Negara, Novindo Pustaka Mandiri, Jakarta.

Universitas Pendidikan Ganesha | 92 
Arifin, Firmansyah et. Al., 2005, Lembaga Negara Dan Sengketa Wewenang Antar Lembaga Negara, cet. I, Konsorsium Reformasi Hukum Nasional, Jakarta.

Asshiddiqie, Jimly, 2004, Konstitusi Dan Konstitusionalisme Indonesia, Mahkamah Konstitusi Republik Indonesia dan Pusat Studi Hukum Tata Negara Fakultas Hukum Universitas Indonesia, Jakarta. 2006, Perkembangan Dan Konsiliasi Lembaga Negara Pasca Reformasi, Sekretariat Jendral Dan Kepaniteraan Mahkamah Konstitusi Republik Indonesia, Jakarta.

, 2009, Pengantar Ilmu Hukum Tata Negara, Raja Grafindo Persada, Jakarta.

Kelsen,Hans, 2007,Teori Umum Hukum Dan Negara : Dasar-Dasar Ilmu Hukum Normatif Sebagai Ilmu Hukum Deskriptif Empirik, Bee Media Indonesia, Jakarta.

Kusnardi, Moh., dan Harmaily Ibrahim, 1988, Pengantar Hukum Tata Negara Indonesia, Sinar Bakti, Jakarta Selatan.

Pieris, John dan Aryanthi Baramuli Putri, 2006, Dewan Perwakilan Daerah Republik Indonesia : Studi, Analisis, Kritik Dan Solusi Kajian Hukum Dan Politik, cet. II. Pelangi Cendekia, Jakarta.

Seidman, Ann, Robert B. Seidmann dan Nalin Abeyserkere, 2002, Penyusunan Rancangan Undang-Undang Dalam
Perubahan Masyarakat

Yang Demokratis : Sebuah Panduan Untuk Pembuat Rancangan Undang-Undang, terjemahan Johanes Usfunan, et. al., ELIPS.

Soeprapto, Maria Farida Indrati, 2006, llmu PerundangUndangan : Dasar-Dasar Dan Pembentukannya, Kanisius, Yogyakarta. 2007, Ilmu PerundangUndangan : Proses Dan Teknik Pembentukannya. Kanisius, Bandung.

Jurnal/Makalah

Philipus M. Hadjonet. Al., 1999, Majalah Yuridika Volume 14 Nomor 6 November-Desember 1999.

\section{Karya Ilmiah}

Subawa, Made, 2003, "Implikasi Yurudis Pengalihan Kekuasaan Membentuk Undang-Undang Terhadap Sistem Ketatanegaraan Republik Indonesia Pasca Perubahan Undang-Undang Dasar 1945" Disertasi Fakultas Hukum Universitas Airlangga, Surabaya.

\section{Peraturan Perundang-Undangan}

Undang-Undang Dasar Negara Republik Indonesia Tahun 1945.

Undang-Undang Nomor 12 Tahun 2011 Tentang Pembentukan Peraturan PerundangUndangan, Lembaran Negara Republik Indonesia Tahun 2011 Nomor 82, Tambahan Lembaran Negara Republik Indonesia Nomor 5234. 